\title{
Factors Affecting Implementation of Performance Appraisal in Public Secondary Schools in Kenya: A Survey of Kirinyaga Central Sub County
}

\author{
Anne Nyokabi Ndirangu ${ }^{1}$, Dr. Esther Waiganjo, $\mathbf{P h D}^{2}$ \\ ${ }^{1}$ Master's Student, Jomo Kenyatta University of Agriculture and Technology, School of Entrepreneurship, Procurement and Management, P. \\ O. Box 62000-00200, Nairobi, Kenya \\ ${ }^{2}$ Jomo Kenyatta University of Agriculture and Technology, School of Entrepreneurship, Procurement and Management \\ P. O. Box 62000-00200, Nairobi, Kenya
}

\begin{abstract}
The study sought to determine the factors affecting the implementation of performance appraisal in selected public secondary schools at Kirinyaga Central Sub County in Kenya. The study covered aspects of key result areas and resources. The study was a survey covering a stratified sample of 150 respondents drawn from 450 employees of the selected schools in Kirinyaga Central Sub County. Data collection in this study was through giving questionnaires to principals, deputy principals as well as other teachers in the 15 schools which were sampled from the 35 schools in the sub county. Data collected through self-administered questionnaire was analyzed using descriptive and inferential statistical tools. Data collected was coded and entered into the computer for data analysis using the SPSS version 21. The study achieved a response rate of $92 \%$ which was excellent in achieving accurate results. The researcher then analyzed the data by calculating the correlation coefficients of each independent variable with the dependent variable. Key result areas had a strong and positive correlation with implementation of performance appraisal with correlation coefficient of 0.892 . Similarly resources also had a strong and positive correlation with implementation of performance appraisal with correlation coefficient of 0.934. The analyzed results further showed that the two variables: key result areas, and resources were statistically significant in influencing teachers' productivity improvement but resources had a stronger relationship with implementation of performance appraisal. It was then concluded that the implementation of performance appraisal in public secondary schools in Kenya has been affected by lack of training of the appraisers and some of the recommendations are that the government should provide resources for implementation, all teachers should be trained on performance appraisal assessment and that the teachers service commission of Kenya should give teachers well defined job descriptions especially on issues of disciplining of students. Furthermore the study recommends that secondary schools in Kenya and specifically Kirinyaga Central Sub County should evaluate all the avenues through which they can increase resources. These resources would help teachers acquire better working tools which will help them achieve their targets.
\end{abstract}

Keywords: Performance Appraisal, Key Result Areas, Resources, Public Secondary Schools in Kenya, Kirinyaga Central Sub County.

\section{Background}

Performance appraisal is the process of evaluating how well employees perform their jobs when compared to a set of standards and then communicating that information (Armstrong, 2009). Other scholars have different definitions for the term, Performance appraisal basically is a process of assessment to compare what an employee has achieved and what the employee had targeted to achieve in a specified duration. According to Bitange, Kibet, and Magutu (2010), the history of performance appraisal is quite brief. Its roots in the early 20th century can be traced to Taylor's pioneering Time and Motion studies. As a distinct and formal management procedure used in the evaluation of work performance, appraisal really dates from the time of the Second World War - now more than 60 years ago. In the $1950 \mathrm{~s}$ in the United States, the potential usefulness of appraisal as tool for motivation and development was gradually recognized but its implementation has been a challenge. The general model of performance appraisal, as it is known today, began from that time.

\section{Research Problem}

According to Okeyo, (2013) the system is being embraced in the Kenyan public service particularly in public secondary schools for tracking employees' performance in service delivery but the method of its implementation has remained a head ache to many, resulting to lack of proper measure of the productivity and employee motivation modalities.

With a number of teachers working for the common results in a school, it has been difficult to know those who are working hard and those who are not, hence performance appraisal was introduced by the ministry of education for this purpose as well as the basis of promotion and helping in identifying training needs of the teachers. The implementation of performance appraisal has not been successful in many public schools in Kenya (Chebet, 2013).

In the public secondary schools in Kirinyaga County, like in other areas in public sector, the performance appraisal was introduced in the last decade aimed at assisting in determining the level of productivity of the individual teachers. Implementation of performance appraisal has remained a challenge in the county. The poor performance in most cases is as a result of some specific teachers not meeting the expectations in their areas as stipulated in the performance appraisal, pulling down the general performance of the secondary school within the county and in Kenya at large. The lack of implementation teams in schools, results areas not well defined, resources not adequate as well as the poor appraisal methods are deemed 


\section{International Journal of Science and Research (IJSR) \\ ISSN (Online): 2319-7064}

Index Copernicus Value (2013): 6.14 | Impact Factor (2014): 5.611

to be the cause of this problem (Waweru \& Orodho, 2013). This study tried to bridge that gap and looked at the factors affecting the performance appraisal in public secondary schools in Kenya a survey of Kirinyaga central sub county.

\section{Purpose of the Study}

The major aim of this study was to establish the factors affecting implementation of performance appraisal in public secondary schools in Kenya, a survey of Kirinyaga Central Sub County. Specifically the study sought to determine the effect of key result areas and resources on implementation of performance appraisal.

\section{Methodology}

The study used a survey research design survey covering a stratified sample of 150 respondents drawn from 450 employees of the selected secondary schools in Kirinyaga Central Sub County. Data collection in this study was through giving questionnaires to principals, deputy principals as well as other teachers in the 15 schools which were sampled from the 35 schools in the sub county. Data collected through self-administered questionnaire was analyzed using inferential statistical tools. Inferential statistics such as correlation analysis was used to determine the relationship between the variables. Data collected was coded and entered into the computer for data analysis using the SPSS version 21.

\section{Results and Analysis}

To determine the extent of the relationship between the various independent variables and the dependent variable, the implementation of performance appraisal, further analysis was done using Pearson Correlation. According to Mugenda and Mugenda, (2003) correlation technique is used to analyze the degree of relationship between two variables. The computations of correlation coefficient yields coefficients in the range -1 to +1 , which is called ( $\mathrm{r}$ ) and indicates the relationship between the two variables. The bigger the coefficient (r) the stronger the relationship between the two variables being compared (Carver, Scheier, \& Segerstrom, 2010).

\subsection{Key Result Areas and Implementation of Performance Appraisal}

The first objective of the study sought to determine the effect of key result areas on implementation of performance appraisal. The results indicate that majority of the respondents supported by $51 \%$ strongly disagreed that discipline of students is well outlined in the job description, and most of the respondents' $56.6 \%$ supported that the academic performance of students is affected by other factors apart from teachers effort. However most of the respondents supported by $58 \%$ indicated that teachers face many challenges while quantifying the results or the impact of counseling. From the correlation findings in Table 1, there was a strong positive and significant relationship between discipline of students and implementation of performance appraisal $(r=0.978 \& \mathrm{p}$ value $0.018<0.05)$. Academic performance had a strong positive and significant relationship with implementation of performance appraisal ( $\mathrm{r}$ $=0.876 \& \mathrm{p}$ value $0.017<0.05)$. And counseling of students had a strong positive and significant relationship with implementation of performance appraisal $(r=0.821 \& \mathrm{p}$ value $0.026<0.05$ ).

Table 1: Correlation analysis between key result areas and implementation of performance appraisal

\begin{tabular}{|c|c|c|c|c|c|}
\hline & $\begin{array}{c}\text { Implementation of } \\
\text { performance appraisal }\end{array}$ & $\begin{array}{c}\text { Students } \\
\text { discipline }\end{array}$ & $\begin{array}{c}\text { Academic } \\
\text { performance }\end{array}$ & $\begin{array}{c}\text { Counseling of } \\
\text { students }\end{array}$ \\
\hline $\begin{array}{c}\text { Implementation of } \\
\text { performance appraisal }\end{array}$ & $\begin{array}{c}\text { Pearson } \\
\text { Correlation }\end{array}$ & 1 & $.978(* *)$ & $.876\left(^{* *}\right)$ & $.821(* *)$ \\
\hline & p-value &. & .018 & .017 & .026 \\
\hline
\end{tabular}

* Correlation is significant at the 0.05 level (2-tailed).

The results clearly indicate that discipline of students is not well outlined in the job description. The results agree with the findings of Rankin and Kleiner, (1988 cited in Abdullah, 2015 , p. 34) who did a study on effective performance appraisal and found out that the implementation of performance appraisal is affected by lack of clear performance goals and thus has effect on implementation of performance appraisal and hence on teachers productivity improvement.

The results clearly indicate that the academic performance of students is affected by other factors apart from teacher's effort. These results also agree with those of Pettijohn, Pettijohn, and Taylor (2000) who did a study on performance appraisal usage and criteria on sales people and found out that sales people had positive perception of performance appraisal but the criteria used for evaluating their performance were not appropriate since two sales people in the same firm can put the same effort but realize different sales. The one with little sales may have done even more marketing for the company for future improved sales, but rated as poor performer.

The results clearly indicate that teachers face many challenges while quantifying the results or the impact of counseling. These results agree with the findings of Rankin and Kleiner (1988 cited in Abdullah, 2015, p. 35), who did a study on effective performance appraisal and found out that one of the reasons why performance appraisal are not effective in many organizations is that some key result areas are not quantified, they lack quantified level of performance.

\subsection{Resources and Implementation of Performance Appraisal}

The second objective of the study sought to establish the effect of resources on implementation of performance appraisal. According to the results majority of the 


\section{International Journal of Science and Research (IJSR) \\ ISSN (Online): 2319-7064}

Index Copernicus Value (2013): 6.14 | Impact Factor (2014): 5.611

respondents supported by $55.8 \%$ stated that their schools do not set aside funds for the implementation of performance appraisal programms. However most of the respondents supported by $54 \%$ indicated that their schools have don't adequate human resources. Similarly most of the respondents supported by $93.8 \%$ stated that there is no time allocated for performance appraisal in the school calendar of events. As shown in Table 2, there was a strong positive and significant relationship between funds set aside and implementation of performance appraisal $(r=0.961 \& p$ value $0.014<0.05$ ). Human resources had a strong positive and significant relationship with implementation of performance appraisal $(r=0.866 \& \mathrm{p}$ value $0.036<0.05)$. And time allocation for performance appraisal also had a strong positive and significant relationship with implementation of performance appraisal $(r=0.977 \& \mathrm{p}$ value $0.025<0.05$ ).

Table 2: Correlation analysis between resources and implementation of performance appraisal

\begin{tabular}{|c|c|c|c|c|c|}
\hline & & $\begin{array}{c}\text { Implementation of } \\
\text { performance appraisal }\end{array}$ & $\begin{array}{c}\text { Funds are set } \\
\text { aside }\end{array}$ & $\begin{array}{c}\text { Human } \\
\text { Resource }\end{array}$ & $\begin{array}{c}\text { Time allocation for } \\
\text { performance appraisal }\end{array}$ \\
\hline $\begin{array}{c}\text { Implementation of } \\
\text { performance appraisal }\end{array}$ & $\begin{array}{c}\text { Pearson } \\
\text { Correlation }\end{array}$ & 1 & $.961(* *)$ & $.866(* *)$ & $.977(* *)$ \\
\hline & p-value &. & .014 & .036 & .025 \\
\hline
\end{tabular}

** Correlation is significant at the 0.01 level (2-tailed).

The results clearly indicate that the respondent schools do not set aside funds for the implementation of performance appraisal programms. The results agree with those of a study by Richu (2007) on teachers perception of performance appraisal in Nakuru and found out that the perception of teachers on performance appraisal is negative and the frequency of appraisal very few.

The results clearly indicate that the respondents in their schools don't adequate human resources. These results agree with those of Eslami and Gharakhani (2012) who found out that one of the reasons for performance appraisal failure is human related, that is discussing results.

The results clearly indicate that there is no time allocated for performance appraisal in the school calendar of events. The results agree with those of a study by Seniwoliba (2014) on effective staff appraisal and productivity in local governments in Ghana and found out that performance appraisal activities are not scheduled in the annual activities and that senior officer's request to be appraised when they need promotion.

\section{Conclusion}

The general objective of the study was to investigate the factors influencing the implementation of performance appraisal in public secondary schools in Kenya. Findings from in this study it was concluded that the current situation is that implementation of performance appraisal in public secondary schools in Kenya has not been successful despite the fact that it was supposed to be adopted a decade ago. Findings have further concluded that the variables used in the study, key result areas and resources had strong positive correlation coefficients with the dependent variable, the implementation of performance appraisal. It was evident from the study that all the parameters used had positive and significant influence on implementation of performance appraisal, and hence worth being addressed. Training of members of the working team, the appraisers was noted to have a big influence on implementation. The study also revealed that the fact that some of the key result areas of teachers are not measureable, like counseling of students, implementation has been negatively affected. It can then be concluded that that even if other factors are addressed the nature of results of some of the key result areas, those that are not measureable remain a challenge in the implementation of performance appraisal.

\section{Recommendations}

To improve on teacher's productivity the teachers service commission of Kenya should consider coming up with a well defined job description for all the teachers to avoid ambiguity, key result areas like discipline of students should be well outlined and teachers should again be trained on how to handle these discipline issues in schools. Children rights in the new constitution of Kenya of 2010 have also greatly affected student discipline in schools which affects their academic performance. The Ministry of education in Kenyan should consider reviewing of some clauses in that article. Teachers Service Commission of Kenya should organise training workshops for all teachers, those being appraised and those who appraise others as it would hep to equip the appraises with the necessary skills and those to be appraised thus simplifying the process of performance appraisal. The secondary schools in Kenya and specifically Kirinyaga Central Sub County need to evaluate all the avenues through which they can increase resources. This could be establishment of income generating projects like farming where there is enough land. Resources, monetary and non monetary are necessary to help teacher acquire tools of work, books and other teaching and learning resources which will help them achieve their targets. Funds are also needed for implementation of performance appraisal, for the various activities in the process of implementation.

\section{References}

[1] Abdullah, F. (2015). Values in Management: Cultural Restructure for an Effective Performance Appraisal. International Journal of Business, Economics and Law, 6 (2), 33-38.

[2] Armstrong, M. (2009). Armstrong's handbook of human resource management practice (11th ed.). London: Kogan Page Limited.

[3] Bitange, R., Kibet, K. S., \& Magutu, P. O. (2010). The effectiveness of performance appraisal systems in private universities in Kenya: an assessment of Kabarsk 


\section{International Journal of Science and Research (IJSR) \\ ISSN (Online): 2319-7064}

Index Copernicus Value (2013): 6.14 | Impact Factor (2014): 5.611

University performance appraisal systems. African journal of business management, 1 (12).

[4] Carver, C. S., Scheier, M. F., \& Segerstrom, C. S. (2010). Optimism. Clinical Psychology Review, 30, 879-889.

[5] Chebet, R. (2013). Empowerment of Teachers and Peformance of Private Secondary Schools in Bomet Count, Kenya. University of Nairobi, Department of Business Administration. Nairobi: University of Nairobi.

[6] Eslami, J., \& Gharakhani, D. (2012). Organizational Commitment and Job Satisfaction. Journal of Science and Technology, 2 (2), 85-91.

[7] Mugenda, O. M., \& Mugenda, A. G. (2003). Research methods: quantitative and qualitative approaches. Nairobi: ACTS Press.

[8] Okeyo, D. O. (2013). Banking on Change Project Final Evaluation Report. Unpublished report submitted to CARE Kenya, Nairobi.

[9] Pettijohn, C. E., Pettijohn, L. S., \& Taylor, A. J. (2000). An Exploratory Analysis of Salesperson Perceptions of the Criteria Used in Performance Appraisals, Job Satisfaction and Organizational Commitment. The Journal of Personal Selling and Sales Management, 20, 77-80.

[10] Rankin, G. D., \& Kleiner, B. H. (1988). Effective Performance Appraisal. Industrial Management \& Data Systems, 88, 13-17.

[11] Richu, A. (2007). A survey of Teachers Perception of Performance Appraisal Practices in Public Secondary Schools in Nakuru District. Nairobi, Kenya: University of Nairobi.

[12] Seniwoliba, J. A. (2014). Assessing the performance appraisal concept of the Local Government Service in Ghana. African Journal of Business Management, 8 (15), 599-611.

[13] Waweru, P. N., \& Orodho, A. J. (2013). Management practices and students academic performance in national examinations in public secondary schools in Kiambu County. International Journal of Scientific Research, 5 (2), 472-479. 